\title{
Preface: Science and Public Health: Professor Ada Yonath, Weizmann Institute of Science, Rehovot, Israel, Nobel Laureate in Chemistry, 2009
}

\author{
Lore Leighton $^{1}$
}

\begin{abstract}
Ribosomes are responsible for translating genetic code into protein and thus central components of cell life. Knowledge of their structure provided important potential applications in and understanding of the mode of action of antibiotics and resistance to antibiotics. The work of Professor Ada Yonath on the crystallography of ribosomes led to improvements in crystallization, crystallographic techniques, and x-ray diffraction detection procedures. In 2000 and 2001, Dr. Yonath published the three dimensional structures of the two subunits of bacterial ribosome. There are potential applications for this work, and hopefully science will use such tools to develop new methods to reduce the burden of many diseases. In 2009, Professor Ada Yonath was awarded the Nobel Prize in Chemistry for her structural work on the ribosome.
\end{abstract}

Key Words: Nobel Prize Chemistry 2009, Professor Ada Yonath, Weizman Institute Israel, ribosome, $\mathrm{x}$-ray crystallography, antibiotic resistance, science and public health

Recommended Citation: Leighton, L. Science and Public Health: Professor Ada Yonath, Weizmann Institute of Science, Rehovot, Israel, Nobel Laureate in Chemistry, 2009. Public Health Reviews. 2013;34: epub ahead of print.

\section{BACKGROUND}

Professor Ada Yonath grew up in a poor family in Israel with a father who was quite ill. However, even as a young child she was always very curious about the world and despite their difficulties her parents sent her to a prestigious grammar school. Professor Yonath's father passed away when she was 11 years old, and from that time onwards she had to help her struggling mother to meet the financial needs of the family with various

\footnotetext{
${ }^{1}$ Public Health Reviews, Presses de l'EHESP, Paris and Rennes, France
} 
odd jobs and by tutoring younger students. However, her mother still supported Professor Yonath's desire to keep learning and she attended high school in Tel Aviv. After high school she served her compulsory military service and was fortunate enough to be placed in the "top secret" office of Medical Forces where she was exposed to medical issues.

\section{STUDIES AND TRAINING}

Professor Yonath began her higher education studies at the Hebrew University in Jerusalem where she received undergraduate and master degrees in chemistry, biochemistry, and biophysics. She then moved on to her doctorate work in x-ray crystallography at the Weizmann Institute where she attempted to attain a high-resolution structure of collagen. ${ }^{1}$

After her $\mathrm{PhD}$, Professor Yonath began her postdoctoral work on fibrous muscle for a year at the Mellon Institute in Pittsburg Pennsylvania. Thereafter, she moved to the Massachusetts Institute of Technology (MIT) to study the structure of a globular protein, staphylococcus nuclease in the laboratory of Professor F. Albert Cotton. ${ }^{2}$

\section{RIBOSOME STUDIES}

In 1970 Professor Yonath returned to the Weizmann Institute and set up the first biological crystallography lab in Israel. Early work in her laboratory focused on understanding protein denaturation and folding. ${ }^{3-5}$ She began to focus her energies on protein biosynthesis, which was one of the major unanswered questions for living cells. At the time the ribosome was known to be responsible for translating genetic code into protein and central to life. But without a structural understanding, scientists were unable to get a true picture of how it functions. In December 1979, Professor Yonath embarked on a long and formidable process aimed at determining the three dimensional structure of the ribosome.

Professor Yonath's work was met with skepticism and even ridicule from the scientific community towards this endeavor. However, she did find both academic and financial support and collaboration from the late Professor H.G. Wittmann of the Max Plank Institute for Molecular Genetics in Berlin. Her early work on the ribosome was also financially supported by the Weizmann Institute and by a grant from the United States National Institutes for Health (NIH). Eventually in 1988, the Helen and Milton A. Kimmelman Center for Biomolecular Structure \& Assembly was established at the Weizmann Institute where Professor Yonath leads a team 
of researchers from around the world. She was appointed director of the Center in 1989.

In order to determine a three-dimensional structure, crystals of the molecule under study are needed. The ribosome is a readily deteriorating, large, flexible, intricate complex of proteins and RNA chains with no internal symmetry, which makes it terribly difficult to obtain crystals. "Because of the difficulties to make crystals of ribosomes that are suitable for measurements people thought for a very long time that it was impossible to obtain this structure by crystallography. The pioneer in this venture has been Ada Yonath," acknowledged Måns Ehrenberg in the 2009 Nobel Prize in Chemistry Award announcement. ${ }^{6}$ Thanks to work at Weizmann and Max Plank the first micro crystals were obtained in the early 1980s. ${ }^{7}$ Professor Yonath was inspired by an article she read at the time about how the cells of winter sleeping bears pack ribosomes in an orderly way and concluded that under stressful conditions this is a natural mechanism for preserving non-deteriorated ribosomes. Therefore she decided to use ribosomes from organisms living in harsh conditions. This led her to bacteria that live in extreme environments in the Dead Sea, thermal springs and atomic piles.

By the mid 1980s Professors Yonath and Wittmann were able to visualize a tunnel spanning the large subunit of the Bacillus stearothermophilus ribosome through which the nascent protein chain could emerge. ${ }^{8}$ In the process of her crystallographic work several novel methods to improve crystallization were developed including the method of cryopreservation of crystals at extremely low temperatures (-185C) to minimize degradation while under x-ray bombardment, which is now commonly used in biological crystallography. ${ }^{9}$

By the mid 1990s, once they had shown that crystallography of ribosomes is feasible, other groups finally came on board. Improvements in crystallization techniques, $\mathrm{x}$-ray diffraction detection facilities and methods to determine diffraction phases led to enhanced resolution. In 2000 and 2001 Professor Yonath published the three-dimensional structures of the two subunits: the small (30S subunit) of the Thermus thermophilus ribosome ${ }^{10}$ and the large (50S subunit) from Deinococcus radiodurans. ${ }^{11}$ This was clearly a pivotal point in her career, but Professor Yonath continued to work on revealing what the structures can tell us about ribosome action. ${ }^{12}$

Another area of investigation by Professor Yonath was the interactions between antibiotics and ribosomes. Ribosomes are a key component for cell life and as a result many antibiotic drugs work by blocking bacterial ribosomal functioning. As stated by Måns Ehrenberg in the 2009 Nobel Prize announcement "Fifty percent of antibiotic drugs have the ribosome as 
their target. How do they bind? This is interesting in itself but then the next thing is how can we use this information to make new drugs and to continue in a successful way to struggle against antibiotic resistance among bacterial pathogens. And all three of [the 2009 Nobel Laureates in Chemistry] have been warriors in the struggle against the rising tide of incurable bacterial infections." "Structures of drug compounds bound to models for pathogenic bacterial ribosomes reveal the means of action of antibiotics and may help improve existing antibiotics and aid in designing new ones (Figure 1). ${ }^{13}$

(A)

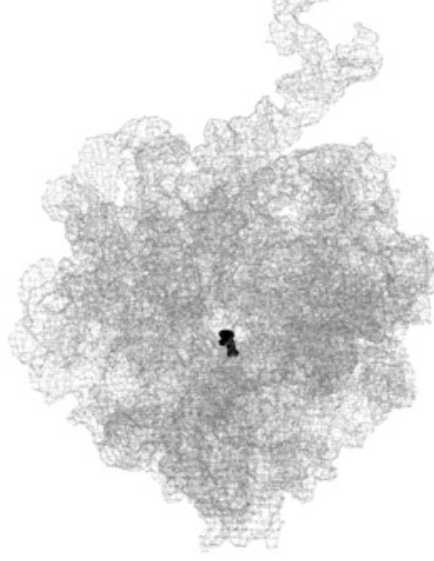

(B)

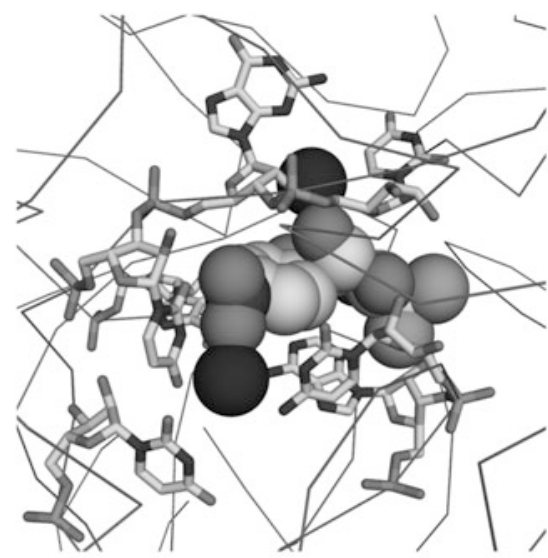

Fig. 1. The antibiotic drug chloramphenicol bound to the peptidyl transferase center of the large (50S) ribosomal subunit of the eubacterium Deinococcus radiodurans. (A) Mesh rendering of the $50 \mathrm{~S}$ ribosomal subunit with chloramphenicol bound (shown in black). (B) Close up view of chloramphenicol (grey spheres) interacting with RNA bases (sticks) in the peptidyl transferase center of the 50S ribosomal subunit and magnesium ions (black spheres). Insights from crystallographic data such as these provide a better understanding of how complex structures function and how drugs interact with them, which can lead to better drug design. The three dimensional atomic coordinates from this structure are deposited at the online Protein Data Bank under the PDB identifier $1 \mathrm{~K} 01 .^{13}$

In her most current work, Professor Yonath is looking into the distant past. The core active site of the ribosome is very well preserved in evolution and found in a diversity of life forms including yeast, bacteria and mammals. Thus, she has suggested that it is the vestige of a primordial apparatus for making peptide bonds and is studying how these first ribosomes came into being and how they evolved into what they are today. ${ }^{14}$ 
In 2009 Professor Yonath was awarded the Nobel Prize in Chemistry along with Professors Venkatraman Ramakrishnan and Thomas A. Steitz for studies of the structure and function of the ribosome. She has received many other awards including the Rothschild Prize for Life Sciences, the Linus Pauling Gold Medal, and the Albert Einstein World Award of Science.

Professor Gunnar Öquist, in his opening statement to the 2009 Nobel Prize announcement, noted that, "The three laureates have accomplished what many scientists had thought impossible, namely to determine the three-dimensional structure of the molecular machine that makes all the proteins in a cell-the so-called ribosome." ${ }^{\prime 6}$ Later in the same press conference, Professor Måns Ehrenberg posed and answered the question, "What is so spectacular about this? [...] Proteins, they control and catalyze chemical reactions and transport components within and between cells in all organisms. Proteins make seeing, hearing, sensing, smelling, muscle movement, talking, and thinking possible. They even make this press conference possible. The rapid and accurate protein making by the ribosome is therefore essential for all lifeforms." ${ }^{6}$

\section{LESSONS FOR PUBLIC HEALTH}

In reflecting on the basic research and career of the estimable Professor Yonath, it is important to understand that health issues do not progress without science. For example, work on the ribosome is able to offer new targets to fight antibiotic resistant bacteria—a pressing challenge to public health in the $21^{\text {st }}$ century. Such fundamental science will influence future knowledge in mental health as well.

\section{REFERENCES}

1. Traub W, Yonath A, Segal DM. On the molecular structure of collagen. Nature. 1969;221:914-7.

2. Arnone A, Bier CJ, Cotton FA, Day Jr VW, Hazen EE, Richardson DC, Richardson JS, Yonath A. A high resolution structure of an inhibitor complex of extracellular nuclease of Staphylococcus aureus. I. Experimental procedures and chain tracing. J Biol Chem. 1971;246:2302-16.

3. Yonath A, Sielecki A, Moult J, Podjarny A, Traub W. Crystallographic studies of protein denaturation and renaturation. 1. Effects of denaturants on volume and X-ray pattern of cross-linked triclinic lysozyme crystals. Biochemistry. 1977;16:1413-7. 
4. Yonath A, Podjarny A, Honig B, Sielecki A, Traub W. Crystallographic studies of protein denaturation and renaturation. 2. Sodium dodecyl sulfate induced structural changes in triclinic lysozyme, Biochemistry. 1977;16:1418-24.

5. Traub W, Yonath A, Podjarny A, Sielecki A, Honig B, Moult J. Crystallographic studies of protein folding. J Biophys. 1977;17:A34.

6. Announcement of the 2009 Nobel Prize in Chemistry. Available from URL: http://www.nobelprize.org/mediaplayer/index.php?id=1168 (Accessed 24 May 2013).

7. Appelt K, Dijk J, Reinhardt R, Sanhuesa S, White SW, Wilson KS, Yonath A. The crystallization of ribosomal proteins from the 50S subunit of the Escherichia coli and Bacillus stearothermophilus ribosome. J Biol Chem. 1981;256:11787-90.

8. Yonath A, Leonard KR, Wittmann HG. A tunnel in the large ribosomal subunit revealed by three-dimensional image reconstruction. Science. 1987;236:813-6.

9. Hope H,Frolow F, von Boehlen K, Makowski I, Kratky C, et al.Cryocrystallography of Ribosomal Particles. Acta Crystallogr B. 1989;45:190-9.

10. Schluenzen F, Tocilj A, Zarivach R, Harms J, Gluehmann M, D. et al. Structure of functionally activated small ribosomal subunit at 3.3 A resolution. Cell. 2000;102:615-23.

11. Harms J, Schluenzen F, Zarivach R, Bashan A, Gat S, et al. High resolution structure of the large ribosomal subunit from a mesophilic eubacterium. Cell. 2001;107:679-88.

12. Bashan A, Agmon I, Zarivach R, Schluenzen F, Harms J, et al. Structural basis of the ribosomal machinery for peptide bond formation, translocation, and nascent chain progression. Mol Cell. 2003;11:91-102.

13. Schluenzen F, Zarivach R, Harms J, Bashan A, Tocilj A, et al. Structural basis for the interaction of antibiotics with the peptidyl transferase centre in eubacteria. Nature. 2001;413:814-21.

14. Davidovich C, Belousoff MJ, Wekselman I, Shapira T, Krupkin M, et al. The proto-ribosome: an ancient nano-machine for peptide bond formation. Isr $\mathrm{J}$ Chem. 2010;50:29-35. 